\title{
OBITUARY
}

\section{Daniel Callahan: In memoriam}

\section{RUTH MACKLIN}

Dan Callahan was a seminal figure in bioethics. In 1969, he co-founded the Hastings Center, one of the first organisations devoted to research and public programmes related to ethics in biology and medicine. The Center is celebrating its 50-year anniversary this year, and sadly, Dan is no longer here to participate in the festivities in the fall. He died on July 16, two days short of his $89^{\text {th }}$ birthday.

Dan did his undergraduate studies at Yale University and received his $\mathrm{PhD}$ in philosophy

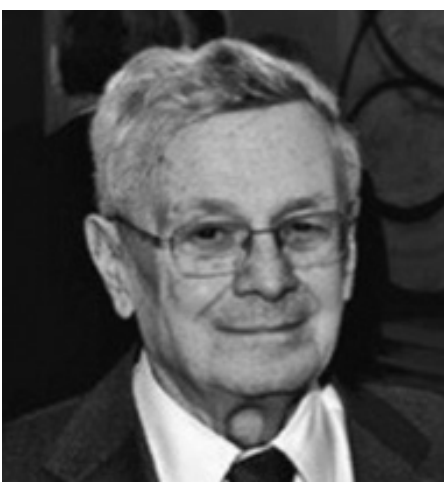

enthusiastically agreed, and the rest is history. As co-leaders of the newly established research centre (at first named the Institute of Society, Ethics, and the Life Sciences), Will was designated as President and Dan's title was Director. In subsequent years, as Will receded somewhat from the day-to-day operations, Dan assumed the title of President. Eventually, they abandoned the unwieldy title of the institution and became officially known as the Hastings Center.

From the outset, Dan and Will decided that from Harvard. By his own admission, he was not suited to being a philosophy professor. The focus on analytic philosophy at the time was too abstract, too removed from the real world. Dan taught briefly before abandoning an academic career. He was always a writer, having published the first of his many books in 1963. After leaving Harvard in 1961, he took a job as an editor of Commonweal, a liberal Catholic magazine. He left the magazine in 1969, having become tired of editing. His next position was with the Population Council in New York, where he spent a year learning about family planning and population policies. The organisation was then the world's leading NGO for family planning policies and contraceptive research. Dan's first major book in the field he was pioneering-Abortion: Law, choice, and morality-was published in 1970. He had received a grant from the Ford Foundation to work on the book and traveled the globe extensively in the late 1960s, researching the topic. It would be many years before Dan turned his attention back to global concerns. He would revisit the topic of abortion in a book he co-edited with his wife, Sidney, a psychologist and pro-life feminist. The book-Abortion: Understanding differences-was a collection of papers written by women on both sides of the contentious issue.

At a Christmas party in 1968, Dan approached psychiatrist Willard Gaylin, his friend and neighbour in the village of Hastings-on-Hudson, New York, with an idea of starting a research centre focused on ethics in medicine. Will Gaylin

Author: Ruth Macklin (ruth.macklin@einstein.yu.edu), Distinguished University Professor Emerita, Albert Einstein College of Medicine, Bronx, NY, USA.

To cite: Macklin R. Danial Callahan: In memoriam. Indian J Med Ethics. 2019 Jul-Sep;4(3)NS:257.DOI:10.20529/IJME.2019.040

Published online on August 5, 2019.

CIndian Journal of Medical Ethics 2019 to keep the new institution independent of a university affiliation, having determined that universities are too political and bureaucratic. Also, at that time-unlike the presentthere was little interdisciplinary research going on in higher education. While Will Gaylin continued his private practice of psychoanalysis and part-time teaching at Columbia University, Dan Callahan threw himself into the job of directing the projects at the Hastings Center and raising money. At the outset, only one other organisation in the United States was devoting its work to bioethics: the Kennedy Institute of Ethics at Georgetown University. As the field grew and interdisciplinary work became more popular, more universityaffiliated centres began to be established in the US and other countries. Yet it was Dan Callahan who put his unique stamp on bioethics at the Hastings Center during his 27 years at the helm.

Dan wrote 17 single-authored books and collaborated as co-author or editor on about 30 additional volumes. His earliest writings were a product of his Catholic background, yet his books were never deeply religious. As his own beliefs moved away from church teachings, he became a leading lay Catholic writer. His first book was entitled The mind of the Catholic layman; two subsequent ones were Honesty in the Church (1965) and The New Church (1966). Dan wrote the latter two while also finishing his $\mathrm{PhD}$ dissertation. Having published three books by the age of 36 , he was well on the way to becoming a prolific writer. He authored most of his subsequent books while at the helm of the Hastings Center, writing grant proposals to support the Center's research, directing day-to-day activities as Director and then President, and responding positively to the many speaking invitations he received. After stepping down as President, he became Director of International Programs at the Center, focusing his work the Center should be multidisciplinary. They also decided 
on countries in Central and Eastern Europe. During his long career, he published hundreds of scholarly articles and essays in a wide variety of journals. Many of his articles appeared in The Hastings Center Report, which Dan founded as the official journal of the Center.

By the early 1970s, Dan's writings became focused on ethics, society, and the life sciences-the original name of the Hastings Center. In 1973 he published The tyranny of survival and Other pathologies of civilized life. Having turned his attention to issues in health policy, his classic work--Setting limits: Medical goals in an aging society--appeared in 1987. That book was highly controversial, as it argued for rationing medical care among generations. 1990 saw the publication of What kind of life, in which Dan questioned the goals of medicine as practised in the US and other industrialised countries. He followed up on the same themes in The troubled dream of life: In search of a peaceful death (1993), focusing on end-of-life care and arguing against euthanasia and assisted suicide. False hopes appeared in 1998, revisiting the topic of the goals of medicine and making a strong case that the quest for unlimited medical progress is a major error. His other books include What price better health? Hazards of the research imperative (2006), Medicine and the market: Equity v. choice (2008), and Taming the beloved beast: How medical technology costs are destroying our health care system (2009). In 2012 Dan published his memoir, In search of the good: A life in bioethics, a compelling account of his early life, his marriage and family, and his long career in the field he helped to found. His last book, The five horsemen of the modern world (2016), explores some of the most serious problems facing the world in the $21 \mathrm{st}$ century: climate change, food and water scarcity, obesity, and chronic illness.

I have been privileged to know Dan Callahan as a colleague, good friend, and even an employee-as a member of the professional staff at the Hastings Center from 1975 to 1980. I met Dan for the first time in 1975 at a workshop sponsored by the Center, where I was one of the speakers and Dan was an attentive listener. A member of the professional staff at the time had just announced his resignation, and Dan offered me the job. I accepted his offer, which meant leaving my position as tenured faculty in a university philosophy department. I never looked back.

Having been previously employed in an academic setting, doing my research and writing at home, I was surprised to find that Hastings Center staff were expected to be present for full workdays (which often lasted until $7 \mathrm{pm}$ or later). As Dan explained, the Center was "halfway between an academic center and a business." What seemed to me at first to be a restriction turned out to be a benefit. The atmosphere at the Center was the most collegial environment I experienced in the 50 years of my professional career. It was the "academic" and not the "business" aspect that enabled us to stop on the way to grabbing a cup of coffee and spend a half hour debating with a colleague the meaning of "justice in health care" or the merits of in vitro fertilisation. Despite his substantial administrative workload, Dan was often a participant in these impromptu discussions. A regular feature of life at the Center was the informal custom of late afternoon drinks on Fridays. At $5 \mathrm{pm}$, we would wander into the kitchen for a glass of wine, where our host (meaning Dan) would be holding forth. The collegiality often spilled over to social events outside the Center, sometimes an impromptu invitation to come over to Dan's for pizza with his wife, Sidney and one or more of their six children. I came to know Dan's children and also became a friend of Sidney's. After almost five years at the Hastings Center, I decided it was time to move on. I left to assume a faculty position at a medical school but continued my association with the Center. Soon thereafter, I was elected as a Fellow.

In the last several years, Dan became increasingly frail and referred to himself as "homebound" because he was no longer driving a car and walking had become difficult. I made regular visits to the couple at their home, which typically involved discussing Dan's current projects and the reception to his latest book. It was a distinct honour for me to be chosen to receive the Hastings Center's prestigious Henry Knowles Beecher award in 2014. The greatest honour, however, was to have known this remarkable thinker and innovator for the past 45 years 